\title{
Effect of Chlorpyrifos and Malathion on Soil Microbial Population and Enzyme Activity
}

\author{
Abhishek Walia ${ }^{1 *}$, Kamaljeet Sumal ${ }^{2}$ and Sudesh Kumari ${ }^{2}$ \\ ${ }^{1}$ Assistant Professor and Head, Department of Microbiology, DAV University, Jalandhar, Punjab, India \\ ${ }^{2}$ Research Scholar, Department of Microbiology, DAV University, Jalandhar, Punjab, India \\ *Corresponding Author: Abhishek Walia, Assistant Professor and Head, Department of Microbiology, DAV University, Jalandhar, \\ Punjab, India. E-mail: sunny_0999walia@yahoo.co.in
}

Received: February 01, 2018; Published: March 12, 2018

DOI: 10.31080/ASMI.2018.01.0033

\section{Abstract}

Pesticides are chemical substances that are used for the protection of crop, plants and vegetables from various insects. Repeated applications of pesticides contaminate the soil and also disturb the soil environment by affecting soil microflora and various physicochemical properties of soil. In view of above problem, the present study examines the effect of different concentrations of chlorpyrifos and malathion (10 - $1000 \mathrm{ppm}$ ) at different incubation period for their impact on various soil microflora and enzyme activities in soil collected from cauliflower field of Jalandhar, Punjab (India). Lower concentration of malathion and chlorpyrifos is beneficial but higher concentration lead to reduction in microbial action in soil. After $250 \mathrm{ppm}$ more declination was found in bacterial populations. Similar results were found in case of actinomycetes populations. However, use of Malathion drastically decreased the fungal population but chlorpyrifos does not have adverse effect on the number. In soil enzyme activities, low conc. has no effect on amylase but activity slightly decreased after $500 \mathrm{ppm}$. Stimulatory effect in cellulase was found at low conc. and inhibitory effect at higher concentrations. Low conc. is beneficial for P- solubilising bacteria but at higher conc. it showed deleterious effect on the phosphatase enzyme. These results concluded that these pesticides have considerably deleterious impact on soil microflora, which may be results in harmful effect on nutrients uptake and plant growth. Malathion showed more adverse effect as compared to chlorpyrifos. This research area merits enhanced future research based on molecular technique, contrary to traditional approach, which are used for quantification of net impact on soil biology.
\end{abstract}

Keywords: Chlorpyrifos; Malathion; Amylase; Cellulase; Phosphatase; Microbial Population

\section{Introduction}

Pesticides are extensively used against a range of pests flourishing agricultural crops. Today, the demand for food is increasing as the population of the world is increasing that leads to sustainability of food production through intensive and modern agriculture attention of public health and proper utilization of natural resources. Pesticides in soil endure a variety of degradative, transport, and adsorption/desorption processes confiding on the chemical nature of the pesticide [1] and soil properties [2] that may modify the physiological and biochemical behaviour of soil microbes. It has been observed that the pesticides exposures are increasingly linked to immune suppression, hormone disruption, diminished intelligence, reproductive abnormalities and cancer.

The production of pesticides started in India in 1952 with the establishment of a plant for the production of BHC near Calcutta, The state of Punjab is one of the highest users of these pesticides especially after the ushering in of green revolution. In Punjab, Malathion and chlorpyrifos has been used from 1970s for the eradica- tion of various insects in fruits, vegetables, cotton, corn, wheat and to remove ticks, termites, roundworms, and mosquitoes. Chlorpyrifos and Malathion has potential risk to humans, mammals, aquatic animals, birds reptiles as they easily penetrated into ground water and soil.

Soil is a living dynamic system containing many free enzymes, immobilized extracellular enzymes and enzymes within microbial cells. Pesticides affects many physiochemical phenomenon involving soil enzymes and microbial population like, the organic matter decomposition and nutrient cycling [3]. The persistence of chlorpyrifos and malathion in human and environment has been reported earlier, but their effect on soil microbes and soil enzymes has not been studied in Jalandhar district of Punjab. The impact of these two is such that the WHO has put three of two "chlorpyrifos and Malathion" to adversely affect $97 \%$ of the 1,782 species listed under the endangered species act. This study also conducted in order to aware the farmers of Punjab about the potential risk to their land and life. 


\section{Materials and Methods}

Soil Sample

The soil used for the experiment was collected from the cropped fields of the cauliflower plants from Jalandhar, Punjab. The soil Samples of $10 \mathrm{~kg}$ soil were collected from the rhizospheric area of the cauliflower plant soil and were collected from 0 to $15 \mathrm{~cm}$ depth and stored at room temperature for 30 days.

\section{Physical Analysis of the soil}

Freshly procured sample of soil were analysed for the physical characteristics. Water holding capacity of soil was determined by filter paper method.

Water holding capacity $\%=\frac{(c-a)-(b-a)}{(b-a)} \times 100$

Weight of empty filter paper $=\mathrm{a}$

Weight of air dry soil $=\mathrm{b}$

Weight of wet soil $=\mathrm{c}$

Soil $\mathrm{pH}$ was determined after shaking the soil with deionized water for 10 minutes by $\mathrm{pH}$ meter.

Effect of Chlorpyrifos and Malathion on Microbial population

Chlorpyrifos and Malathion treatments

$100 \mathrm{mg}$ of soil samples were taken in a eleven petri dishes and each dish was treated with different concentrations of Chlorpyrifos as $10 \mathrm{ppm}$ is $0.7 \mu \mathrm{l}, 100 \mathrm{ppm}$ is $7 \mu \mathrm{l}, 250 \mathrm{ppm}$ is $17 \mu \mathrm{l}, 500 \mathrm{ppm}$ is $35 \mu \mathrm{l}$ and $1000 \mathrm{ppm}$ is $70 \mu \mathrm{l}$ in $1000 \mathrm{ml}$ of chlorpyrifos volume, and also treated with different concentrations of Malathion as $10 \mathrm{ppm}$ is $0.1 \mathrm{ml}, 100 \mathrm{ppm}$ is $1 \mathrm{ml}, 250 \mathrm{ppm}$ is $2.5 \mathrm{ml}, 500 \mathrm{ppm}$ is $5 \mathrm{ml}$ and $1000 \mathrm{ppm}$ is $10 \mathrm{ml}$, contents were mixed gently and incubated at room temperature for 21 days respectively. Soil containing different concentrations i.e. control, 10, 100, 250, 500 and 1000 ppm of Chlorpyrifos and Malathion were incubated at room temperature. Soil samples were taken at $0,1,2$ and 3 weeks of intervals from each concentration.

Quantification of Bacteria, Fungi and Actinomycetes

Enumeration was done by using standard dilution technique. Bacteria, fungi and actinomycetes were inoculated and counted by plating $0.1 \mathrm{ml}$ of suitable dilution on separate plates (spread- plate method) and incubated at $35^{\circ} \mathrm{C}$ and $28^{\circ} \mathrm{C}$, respectively for $72 \mathrm{~h}$. Nutrient agar (NA), Sabouraud dextrose agar (SDA) and casein agar (CA) medium were used for the enumeration of soil bacteria, fungi and actinomycetes respectively.

\section{Enzymatic Determination}

Amylase

Starch agar media was used to inoculate amylase bacterial colonies. Colonies were grown by spread plate technique using $0.1 \mathrm{ml}$ of dilution on plates and incubated at $35^{\circ} \mathrm{C}$ for $48-72 \mathrm{~h}$. Plates with bacterial colonies were then flooded with Gram's iodine reagent. If strain was amylolytic then it started hydrolysing the starch present in the surrounding and in the zone degradation there was no blue colour formation. Selection was done on the basis of clear halozone formed by amylase producing bacteria, respectively.

\section{Cellulase}

The sample of one gram of soil was transferred to $9 \mathrm{ml}$ of distilled water and dilutions were made up to $10^{-3}$ and $0.1 \mathrm{ml}$ of soil suspension was spread on the Carboxymethylcellulose agar (CMC), $\mathrm{pH}$ of the medium was adjusted to 7 . Incubated the plates at $35^{\circ} \mathrm{C}$ for $48-72 \mathrm{~h}$. Plates with bacterial colonies were then flooded with Gram's iodine reagents. If isolates were cellolytic then it started hydrolysing the cellulose present in the surrounding and clear halozone was formed.

\section{Phosphatase}

One gram of soil sample was suspended in $9 \mathrm{ml}$ of distilled water and serial dilution made up to $10^{-3}$ and $0.1 \mathrm{ml}$ of soil suspension was spread on the Pikovskaya's agar (PVK). Plates were incubated at $35^{\circ} \mathrm{C}$ for $48-72 \mathrm{~h}$. Colonies with yellow zone was marked positive for phosphorus solubilisation.

\section{Result and Discussion}

Effect of Malathion and chlorpyrifos on soil bacterial population.

The bacterial population isolated from pesticide treated soil with different concentration of Malathion and chlorpyrifos (10 ppm, 100 ppm, 250 ppm, 500 ppm and 1000 ppm) was studied (Figure 1). Bacterial population was found to be decreased at higher concentration of malathion and chlorpyrifos and on lower concentration there is not much effect of the pesticide on the bacterial population.

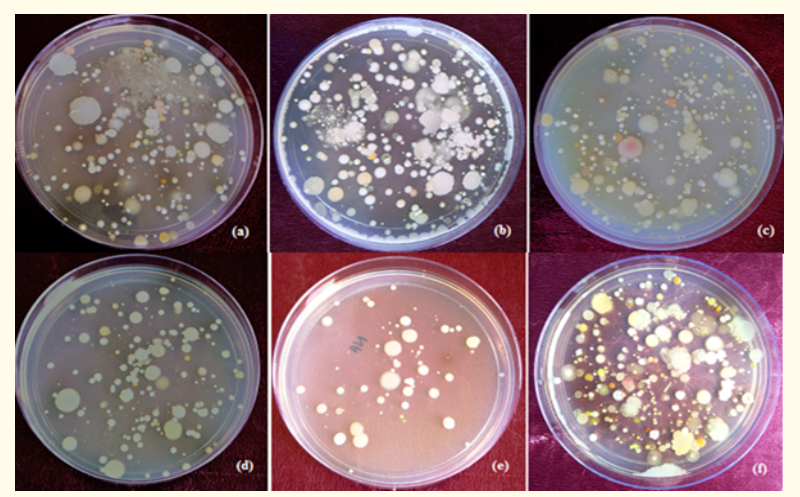

Figure 1: Effect of different concentration of malathion on soil bacteria in nutrient agar medium, (a) $10 \mathrm{ppm}$ (b)100 ppm

(c) 250 ppm (d) 500 ppm (e) 1000 ppm and (f) control.

It was observed that bacterial population in malathion treated soil starts decreasing from $10 \mathrm{ppm}\left(1.97 \times 10^{-6} \mathrm{cfu} / \mathrm{g}\right)$ to $1000 \mathrm{ppm}$ $\left(1.51 \times 10^{6} \mathrm{cfu} / \mathrm{g}\right)$. After $250 \mathrm{ppm}\left(1.7 \times 10^{-6} \mathrm{cfu} / \mathrm{g}\right)$ more declina- 
tion found in the bacterial concentration with $500 \mathrm{ppm}\left(0.95 \times 10^{-6}\right.$ $\mathrm{cfu} / \mathrm{g})$ and $1000 \mathrm{ppm}\left(0.65 \times 10^{6} \mathrm{cfu} / \mathrm{g}\right)$ concentration. Isolation of bacterial population in different concentration was performed on regular 7 days interval from day 1 ( 0 week), day 7 ( $1^{\text {st }}$ week), day 14 ( $2^{\text {nd }}$ week) and day 21 ( $3^{\text {rd }}$ week) onwards as shown in figure 3. It was observed that after 7 days, the bacterial population decreased from $1.92 \times 10^{-6}$ to $1.72 \times 10^{-6} \mathrm{cfu} / \mathrm{g}$ after every week. The most adverse effect was seen with $500 \mathrm{ppm}\left(0.45 \times 10^{-6} \mathrm{cfu} / \mathrm{g}\right)$ and $1000 \mathrm{ppm}$ concentration $\left(0.35 \times 10^{-6} \mathrm{cfu} / \mathrm{g}\right)$, and different scenario was found with $250 \mathrm{ppm}$ during $1^{\text {st }}$ and $2^{\text {nd }}$ week as the number of bacteria increased populations. Whereas chlorpyrifos showed almost similar results during the initial incubation period at low concentration does not affect the bacterial population $\left(1.97 \times 10^{-6}\right.$ $\mathrm{cfu} / \mathrm{g}$ ) as much. During the third week of incubation period, bacterial population increased non-significantly at $250 \mathrm{ppm}\left(0.85 \times 10^{-6}\right.$ to $1.25 \times 10^{-6} \mathrm{cfu} / \mathrm{g}$ ) and above $250 \mathrm{ppm}$, the bacterial population decreased significantly and inhibit bacterial growth at higher concentrations i.e. at $1000 \mathrm{ppm}$ where bacterial population decreased to $0.42 \times 10^{-6} \mathrm{cfu} / \mathrm{g}$.

Similarly studies have shown that both pesticides leads to decrease in bacterial population after 24 hour treatment $[4,5]$. Moreover, it was found that at higher concentration above $250 \mathrm{ppm}$ of both pesticides the number of bacteria declined after every week starting from the first week [6]. But at $250 \mathrm{ppm}$ there was a slight increase in the bacterial populations due to the degradation of pesticides in soil and also the persistence in soil was $7-14$ days in slight alkaline nature of soil [7]. There are contradictory evidences on change in microbial population due to chlorpyrifos application. Researchers have reported non- inhibitory effect on total viable count of any kind of bacteria [8]. Short term inhibitory effect on the total bacterial population [9]. On the other hand, some studies showed significant increase in the same after chlorpyrifos treatments at particular concentration due to the presence of some chlorpyrifos degrading bacteria [10].

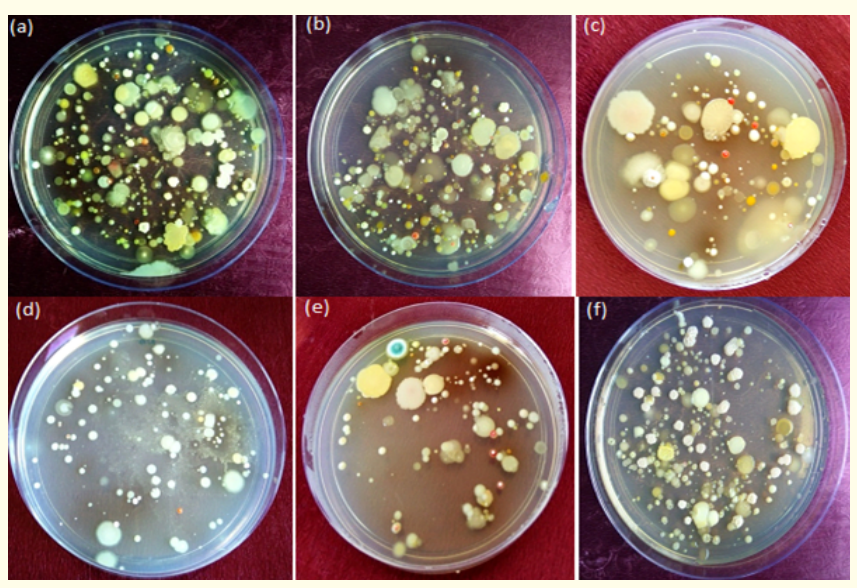

Figure 2: Effect of different concentration of chlorpyrifos on bacterial population in nutrient agar (NA) medium (a) 10 ppm (b) 100 ppm (c) 250 ppm (d) 500 ppm (e) $1000 \mathrm{ppm}$ (f) control.

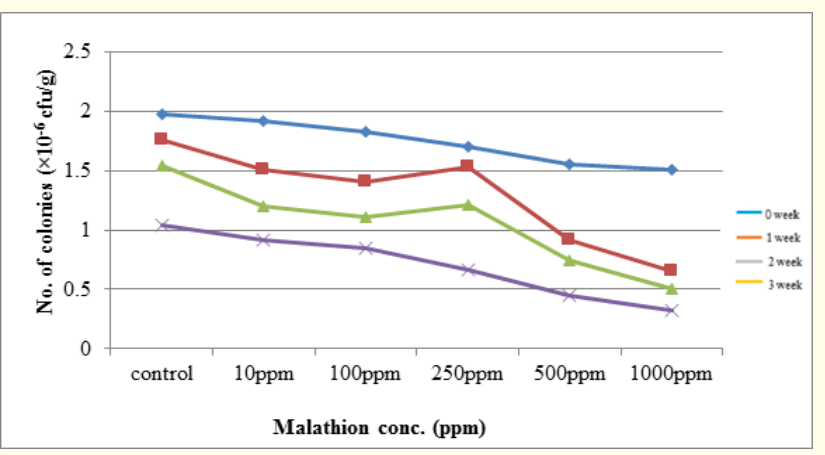

Figure 3: Effect of different concentration of malathion on soil bacterial population.

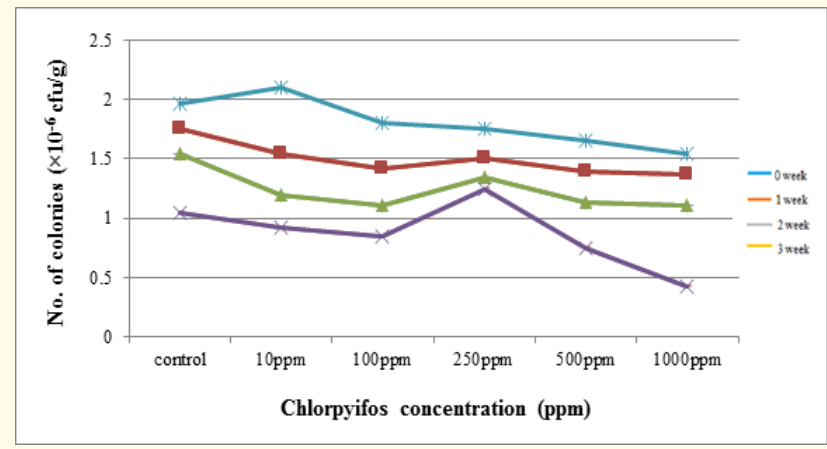

Figure 4: Effect of different concentration of chlorpyrifos on bacterial population.

\section{Effect of Malathion and chlorpyrifos on fungal population}

Fungal population was decreased at higher concentration of malathion and chlorpyrifos and on lower concentration the number of fungi shows slight decline. Fungal population was found to be slightly different at $10 \mathrm{ppm}\left(3.2 \times 10^{-6} \mathrm{cfu} / \mathrm{g}\right)$ and $100 \mathrm{ppm}(2.9 \times$ $\left.10^{-6} \mathrm{cfu} / \mathrm{g}\right)$ concentration as compared to control $\left(4.2 \times 10^{-6} \mathrm{cfu} / \mathrm{g}\right)$. Different types of fungi were isolated with different morphology, shape and colour. But fungal population was decreased drastically at 500 and $1000 \mathrm{ppm}\left(2.1 \times 10^{-6} \mathrm{cfu} / \mathrm{g}\right)$ concentration of Malathion as compared to control. Comparison between numbers of fungal population was compared at different concentration of malathion and chlorpyrifos was shown in figure 5 and 6 .

It was observed that during first seven days of malathion treatment there is slight decrease in fungal population, but after first week of incubation impact on fungal population was adverse and much higher with higher concentration of malathion i.e. $500(0.4 \times$ $\left.10^{-6} \mathrm{cfu} / \mathrm{g}\right)$ and $1000 \mathrm{ppm}\left(0.2 \times 10^{-6} \mathrm{cfu} / \mathrm{g}\right)$. Very few fungal colonies was observed in third week at 500 and 1000 ppm concentration But Chlorpyrifos does not show any adverse effect on fungal populations during initial incubation period of soil sample at 10 ppm. Fungal populations decreased in chlorpyrifos treated soil at concentration above $10 \mathrm{ppm}$ or $100 \mathrm{ppm}$ and degree of reduction depend upon the amount of insecticide applied initially and incubation period of soil sample. 
The total number of fungal population were decreased with higher concentration of malathion up to $800 \mu \mathrm{l}$, while at low concentration they have similar numbers of isolates as reported by Smith., et al. [11] and Tarek., et al [12]. In our study, at higher concentration above $500 \mathrm{ppm}$ there was a decline in fungal population. After 7 days, the effect was more, but later on there was no further decrease and it may be due to degradation of malathion as reported in several reports that many of the fungal species like Aspergillus niger is a very effective biodegrading species of malathion [13]. The degree to which such mechanism will contribute is dependent upon various physiochemical properties of the malathion and soil (Hasan., et al. 1999). It was reported that when chlorpyrifos applied in the soil at lower doses (1 - $2 \mathrm{ppm})$, total CFU count increased between $12.08-13.42 \times 10^{-3} \mathrm{cfu} / \mathrm{g}$ soil. Lower concentration of chlorpyrifos caused a stimulatory effect on fungal population as they probably utilized it as energy source. However, higher concentrations ( $5-500 \mathrm{ppm}$ ) of chlorpyrifos inhibited the total fungal population [14]. Short term inhibitory effect on the total fungal population was observed after chlorpyrifos application in ground nut filed, which recovered within 60 days seed treatments and 45 days of soil treatments $[6,9,15]$.

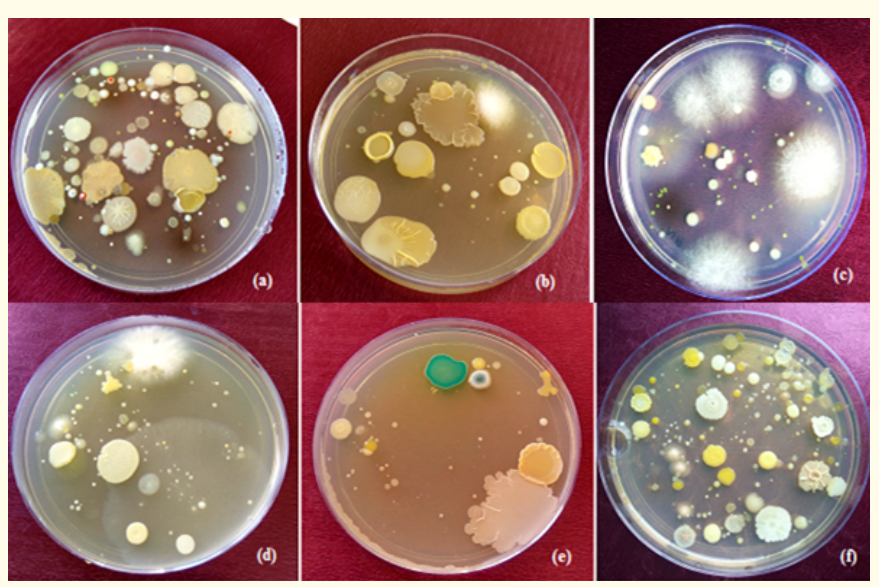

Figure 5: Effect of different concentration of malathion on fungi in SDA medium, (a) 10ppm (b) 100 ppm (c) 250 ppm (d) 500 ppm (e)1000 ppm and (f) control.

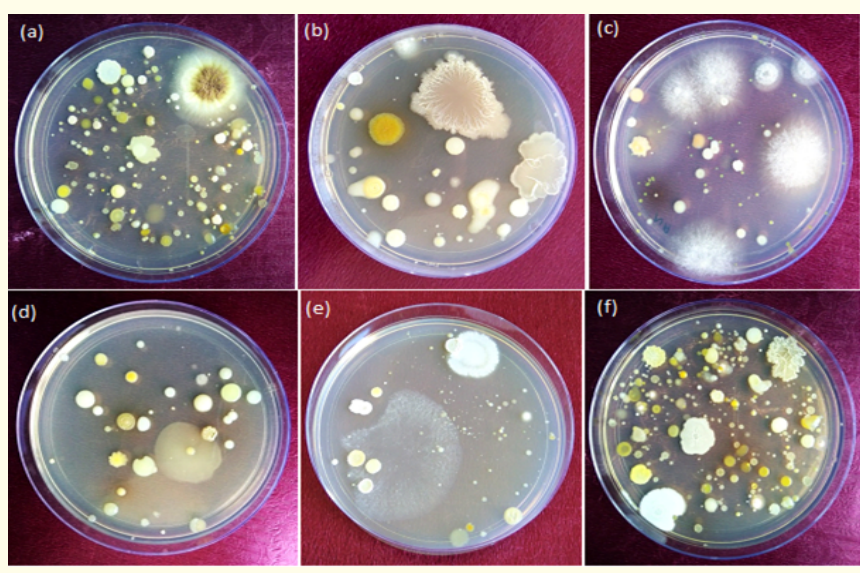

Figure 6: Effects of different concentration of chlorpyrifos on fungal population in sabouraud dextrose agar (SDA) medium (a) 10 ppm (b) 100 ppm (c) 250 ppm (d) 500 ppm (e) 1000 ppm (f) control.

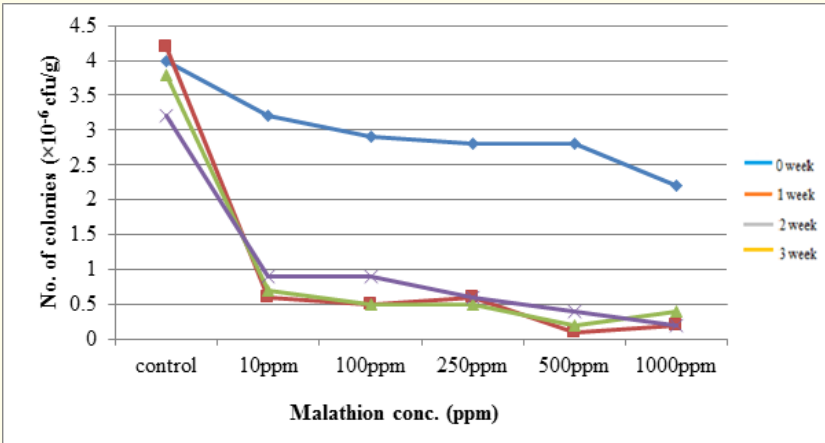

Figure 7: Effect of different concentration of malathion on fungal population.

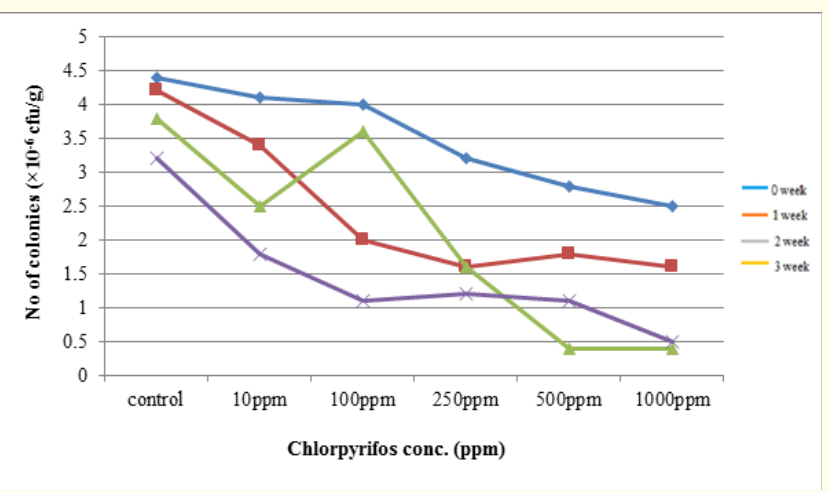

Figure 8: Effect of different concentration of chlorpyrifos on fungal population.

Evaluating the effects of Malathion and chlorpyrifos on soil actinomycetes

Different types of colonies were found in CA medium with different size, shape, appearance and colour. It was observed that in lower concentration of Malathion and chlorpyrifos the effect was very low and with increase in concentration number of actinomycetes decreased. At $10 \mathrm{ppm}\left(5.2 \times 10^{-6} \mathrm{cfu} / \mathrm{g}\right)$ and $100 \mathrm{ppm}(5.1 \times$ $\left.10^{-6} \mathrm{cfu} / \mathrm{g}\right)$ the results were almost equal to control $\left(6 \times 10^{-6} \mathrm{cfu} / \mathrm{g}\right)$ which defines that up to $100 \mathrm{ppm}$, there was no adverse impact of the malathion, but it shows more deleterious effect at higher concentration. Figure 11 showed less decrease in actinomycetes in the first week of incubation period at $100 \mathrm{ppm}\left(5.2 \times 10^{-6} \mathrm{cfu} / \mathrm{g}\right)$, but after that, at $100 \mathrm{ppm}$ there was increase in the decreasing number of actinomycetes population $\left(2.5 \times 10^{-6} \mathrm{cfu} / \mathrm{g}\right)$.

According to the report published [4] the population of actinomycetes decreased on malathion treatment similar results were found during the course of our study. Whereas, in some studies rapid decline in number of actinomycetes was observed using different pesticides [16]. The results obtained from the past and our recent studies, highlights that the application of chlorpyrifos and malathion favoured the actinomycetes growth in the soil at low concentration, thereby inhibiting other micro-organisms [17] and higher concentration sight the reduction in actinomycetes populations [18]. Also indicated that soil microbial and actinomycetes populations were inhibited by chlorpyrifos at $10 \mathrm{mg} \mathrm{kg}^{-1}$ [18]. Comparatively in third week very different results were found in malathion and chlorpyrifos treated soil samples. Contradictory studies have observed during the $3^{\text {rd }}$ week where Malathion shows increase in 
the number of actinomycetes whereas Chlorpyrifos sighted decline in the actinomycetes. Beside that we have detected $250 \mathrm{ppm}$ is the effective concentration in decreasing the actinomycetes as equivalently Haleem described $72.13 \%$ inhibition rate at $250 \mathrm{ppm}$ concentration of Malathion.

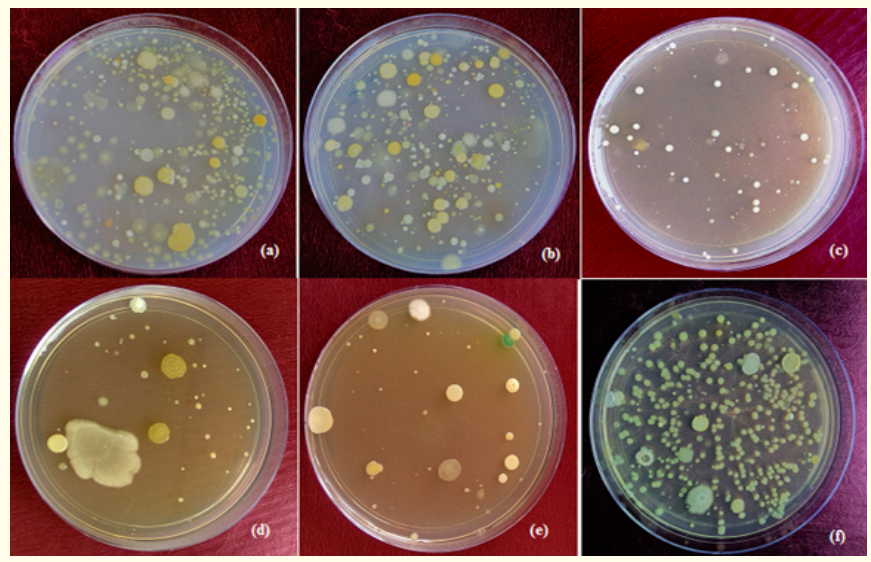

Figure 9: Effect of malathion on actinomycetes in casein agar medium, (a) 10 ppm (b) 100 ppm (c) 250 ppm (d) 500 ppm (e) 1000 ppm and (f) control.

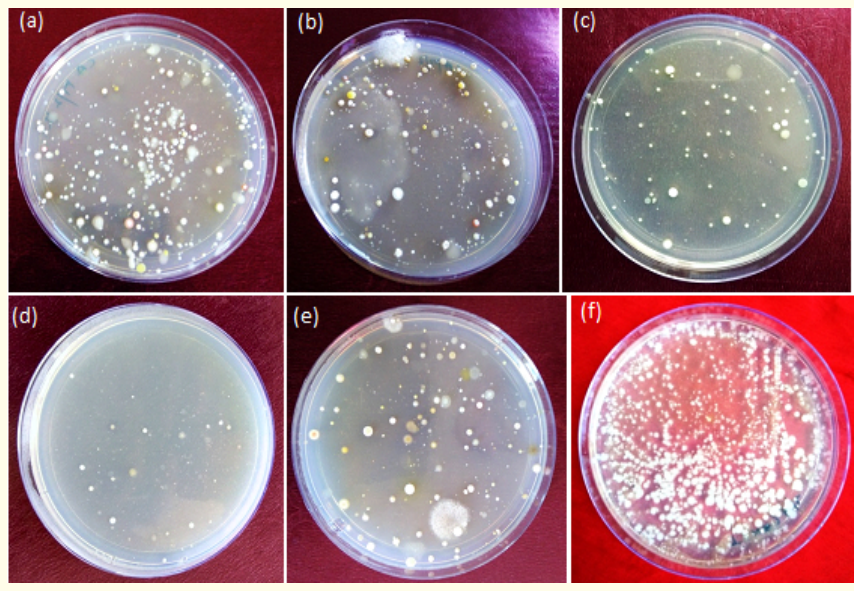

Figure 10: Effects of chlorpyrifos on Actinomycetes population in casein agar (CA) medium (a) 10 ppm (b) 100 ppm

(c) 250 ppm (d) 500 ppm (e) 1000 ppm (f) control.

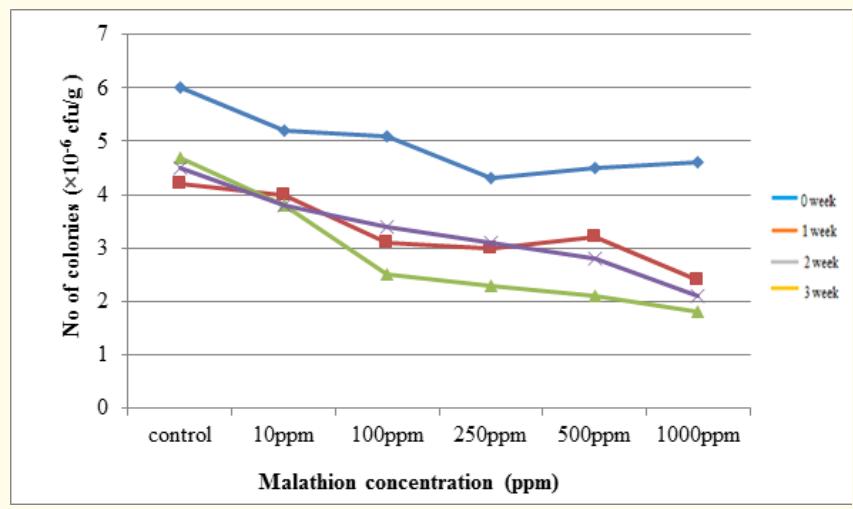

Figure 11: Effect of different concentration of malathion on actinomycetes.

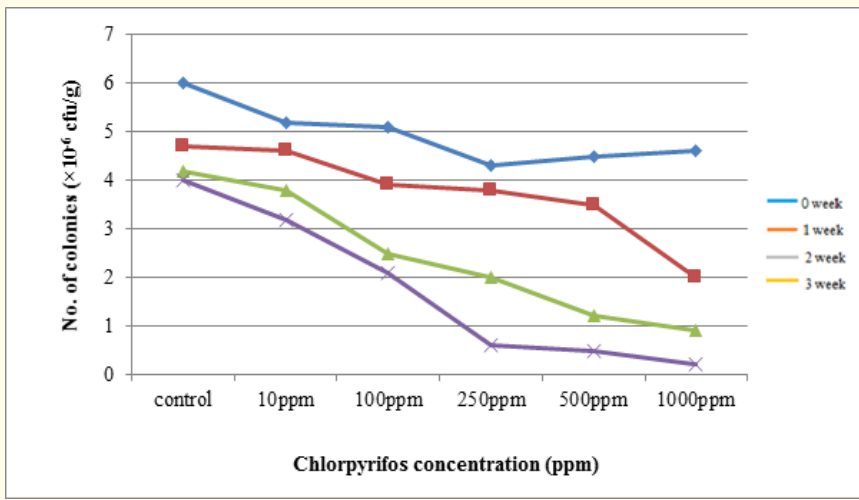

Figure 12: Effect of different concentration of chlorpyrifos on actinomycetes population.

Effects of malathion and chlorpyrifos on soil phosphate solubilizing bacteria

The presence of phosphate solubilising bacteria in soil and the effect of different concentration of malathion and chlorpyrifos on P-solubilizers were studied. Phosphate solubilizing microorganisms were screened by a plate assay method using Pikovskaya's (PVK) agar. Phosphate-solubilizing bacteria were grow by forming a yellow zone around the colony due to phosphate solubilization activity. Maximum number of P-solubilizers were detected in 10 ppm (10.5 × $\left.10^{-6} \mathrm{cfu} / \mathrm{g}\right), 100 \mathrm{ppm}\left(9.8 \times 10^{-6} \mathrm{cfu} / \mathrm{g}\right), 250 \mathrm{ppm}(9.9$ 
$\left.\times 10^{-6} \mathrm{cfu} / \mathrm{g}\right)$ which was at par as compared to control $\left(10.5 \times 10^{-6}\right.$ $\mathrm{cfu} / \mathrm{g}$ ) and showed that there was less effect of both the pesticides on phosphate solubilizers present in the soil. But 1000 ppm concentration was found to be very effective in decreasing the phosphate solubilising ability. But comparatively Malathion shows more adverse effect on phosphate solubilizers (Figure 13,14). During initial two weeks the effect of malathion was very less on P-solubilizing bacteria. In last week, P-solubilizing bacterial population decreased to $0.3 \times 10^{-6} \mathrm{cfu} / \mathrm{g}$. It may be possible that these bacteria are no longer resistance to malathion as during first 14 days. It was observed that low concentration. of pesticide is beneficial for P-solubilizing bacteria but at higher concentration. it showed deleterious effects on microbial population.Effect of malathion on alkaline and acid phosphatase activity showed similar results. On day 0 , malathion did not affect the phosphatase activity very much and the phosphatase activity was found to be same at all concentration of the pesticide. But on 7th day, the activity of alkaline and acid phosphatase was found to decrease with increase in concentration of the pesticide. We have observed elevation in phosphates solubilising bacteriaduring second week in both pesticides as reported by Mahanta on $10^{\text {th }}$ day of Malathion treatment they found slow increase in the activity of alkaline phosphate and decreased later on [19]. Similarly, there was a decline in the phosphatase activity day by day. The effect of different concentration. of the pesticide was not same against the acid phosphatase activity of soil microbes as they show variation during different periods of time. This was because malathions are less effective on soil microbes and their activities [20]. An overall inhibition [21] and reduced activity of alkaline phosphatase to a greater extent [22] proves the detrimental effect of chlorpyrifos on micro-organisms and their enzyme activities. A strong inhibitory effect was observed for phosphatase activity in the presence of chlorpyrifos [23].

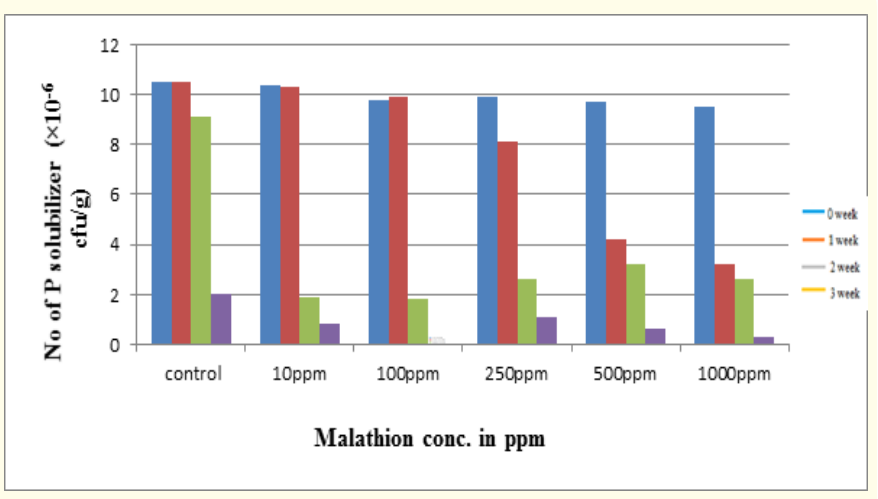

Figure 13: Effect of different concentration of malathion on phosphate solubilizers.

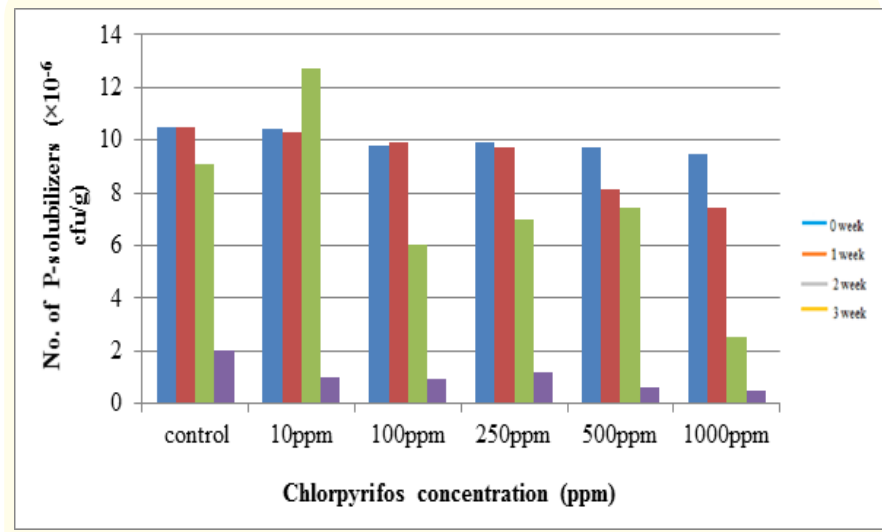

Figure 14: Effect of different concentration of chlorpyrifos on phosphorus solubilizers bacteria.

Effect of malathion and chlorpyrifos on soil amylase activity

The presence of starch hydrolysing enzyme i.e. alpha amylase was detected by growing the bacteria in starch agar medium which breaks down starch to its component glucose molecules and giving clear zone, as starch combines with iodine to form a blue-brown color. If the microbe produces alpha-amylase, the medium in the vicinity of the growth remains amber, indicating that starch near the growth was digested by the alpha-amylase produced by the microbes. It was studied that there are lots of bacteria present in our soil sample that produces alpha amylase and the treatment of malathion and chlorpyrifos does not effects the number of bacterial colonies forming clear zones. At $10 \mathrm{ppm}\left(10.4 \times 10^{-6} \mathrm{cfu} / \mathrm{g}\right), 100$ $\operatorname{ppm}\left(9.8 \times 10^{-6} \mathrm{cfu} / \mathrm{g}\right), 250 \mathrm{ppm}\left(9.9 \times 10^{-6} \mathrm{cfu} / \mathrm{g}\right), 500 \mathrm{ppm}(9.7 \times$ $\left.10^{-6} \mathrm{cfu} / \mathrm{g}\right)$ and $1000 \mathrm{ppm}\left(9.6 \times 10^{-6} \mathrm{cfu} / \mathrm{g}\right)$ there were no difference in the number of amylase producers as compared to control $\left(10.5 \times 10^{-6} \mathrm{cfu} / \mathrm{g}\right)$ in malathion treated soil samples, but a slight decrease was found in $500 \mathrm{ppm}$ and $1000 \mathrm{ppm}$ concentration of Malathion and chlorpyrifos after first week.

During initial 14 days, the activity of amylase enzyme or the bacterial colonies producing alpha amylase was found to be almost constant and very slight difference was observed at $500 \mathrm{ppm}(6 \times$ $\left.10^{-6} \mathrm{cfu} / \mathrm{g}\right)$ and $1000 \mathrm{ppm}\left(5 \times 10^{-6} \mathrm{cfu} / \mathrm{g}\right)$ as compared to control $\left(8 \times 10^{-6} \mathrm{cfu} / \mathrm{g}\right)$. In next 2 nd week of malathion and chlorpyrifos incubation, decrease in the amylase activity was found, whereas in 3rd week again, the activity was decreased in malathion treated plates than chlorpyrifos only in higher concentration i.e. from 250 to $1000 \mathrm{ppm}\left(1.8 \times 10^{-6} \mathrm{cfu} / \mathrm{g}\right.$ to $\left.0.9 \times 10^{-6} \mathrm{cfu} / \mathrm{g}\right)$. 
Soil enzymes are their major living activity of the rhizosphere affecting nutrient cycling and nitrogen fixation. The activities of amylase was influenced by insecticide interactions according to which the lower concentration showed enhancement in the activities (i.e. $10 \mu \mathrm{g}$ ) whereas, the higher concentration $(25 \mu \mathrm{g})$ exhibited an antagonistic effect against both amylase and cellulase enzymes [24]. In our present study, malathion only effect the amylase activity of soil only at higher concentration (500 ppm and $1000 \mathrm{ppm}$ ), rest of the concentration do not or very less differences from control. Amylase was reported to show variable pattern in response to different pesticides concentration, the activity of amylase was observed to be increased with lower dosages, black clay soil, and up to 20 days of incubation and after that it was decreased. Our study shows increase in amylase activity after 10 from $100 \mathrm{ppm}$ to 1000 ppm concentration and equivalently reported in chlorpyrifos treated soil shows inhibitory effect on amylase activity. Because of organic matter decreased and chlorpyrifos was degraded and amylase activity restored to its original level gradually during day 5 to day 15 [25]. Some researcher found the stimulation on addition of pesticides at lower concentration on amylase activity while higher concentrations showed antagonistic effects [26]. Experimental facts shows that amylase activity was not influenced as much by the treatments of chlorpyrifos and malathion. Our results are well justified because during first two weeks there were no inhibition against amylase activity, but after that in third week there was decline in the activity.

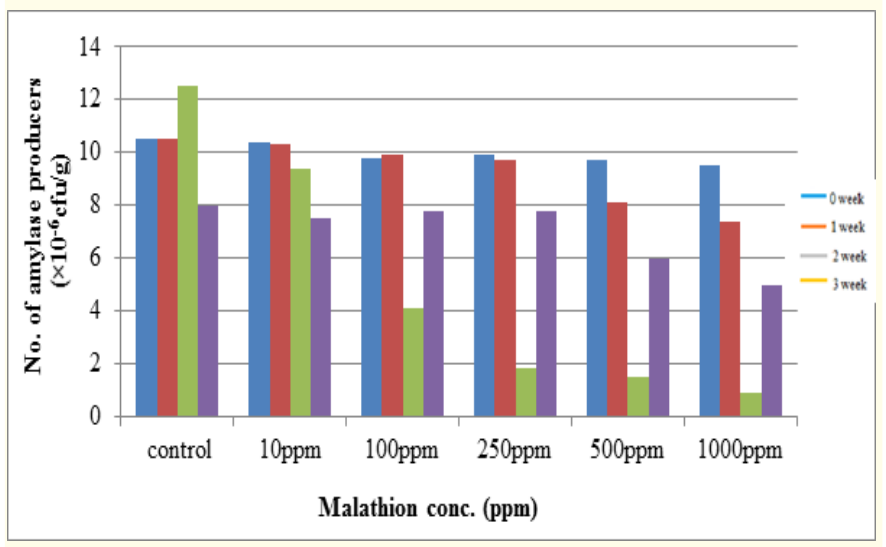

Figure 15: Effect of different concentration. of malathion on amylase activity.

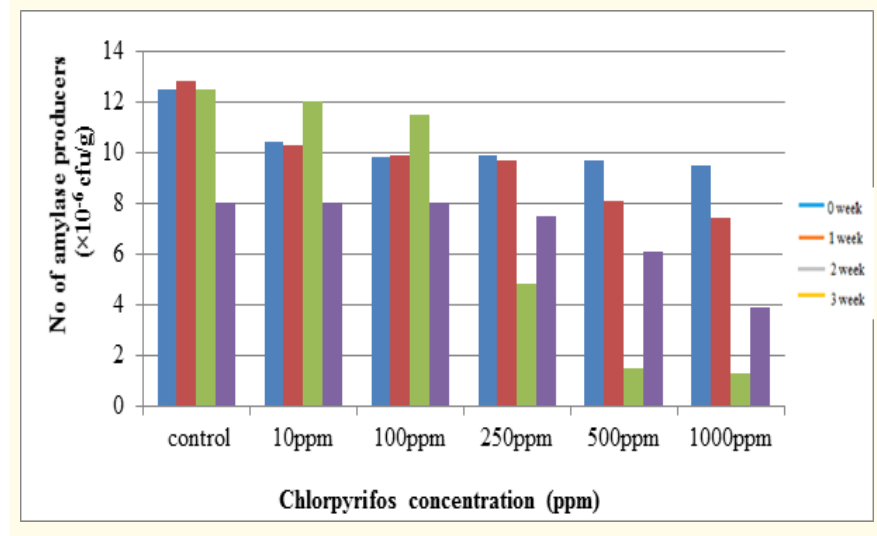

Figure 16: Effect of different concentration of chlorpyrifos on amylase producers.

Effects of malathion and chlorpyrifos on soil cellulase activity

Effect of different concentration of chlorpyrifos was observed on cellulase producers in CMC medium (Figure 16) Extracellular cellulase production by bacteria and fungi was done on agar plates containing cellulose as substrate in carboxymethylcellulose (CMC) agar medium. The detection of cellulolytic activity was achieved by staining with iodine that formed clear zones in the area that surround the source of cellulase enzyme. It was reported that the presence of cellulase enzyme in different concentration of malathion and chlorpyrifos have not so much effect on the cellulase enzyme activity. Comparatively at much higher concentration of malathion i.e. $500\left(10.4 \times 10^{-6} \mathrm{cfu} / \mathrm{g}\right)$ and $1000 \mathrm{ppm}\left(10.2 \times 10^{-6} \mathrm{cfu} / \mathrm{g}\right)$ decreased the enzyme activity than chlorpyrifos at $500 \mathrm{ppm}(14 \times$ $\left.10^{-6} \mathrm{cfu} / \mathrm{g}\right)$ and $1000 \mathrm{ppm}\left(13.7 \times 10^{-6} \mathrm{cfu} / \mathrm{g}\right)$ and similarly in chlorpyrifos treatment showed stimulatory effect at lower concentration but inhibitory effect at higher concentration The average inhibition of celluase producers was observed at $500 \mathrm{ppm}$ and 1000 ppm of chlorpyrifos after 7 days of incubation period (Figure 18).

It was observed that the impact of malathion on enzyme activity was not deleterious. During first seven days, there was slight decrease in enzyme activity but in subsequent days impact was almost equal to control $\left(10 \times 10^{-6} \mathrm{cfu} / \mathrm{g}\right)$ and slightly decreased at higher concentration 500 and $1000 \mathrm{ppm}\left(7.1 \times 10^{-6} \mathrm{cfu} / \mathrm{g}\right.$ to $6.2 \times 10^{-6} \mathrm{cfu} / \mathrm{g}$ ) after three weeks. Interaction effects of organo- 
phosphatase and other insecticides were reported to be effect the cellulase activity in soil, as activity of cellulase increased with insecticides at a lower concentration because of synergistic effect whereas at higher concentration have antagonistic effect on cellulase activity [24]. Similarly, in our present study, there was very less difference in the activity of cellulase during the 20 days of our experiments. Differences were only found at the higher concentration of 500 ppm and 1000 ppm. Very few studies were conducted on activities of cellulase enzyme under the impact of chlorpyrifos in modern agriculture [27] stated that addition of chlorpyrifos promoted cellulase activity at 50ppm but in our recent study it doesn't show any decrease or increase during first 24 hour. Decrease in the cellulase activity was found at very low concentration of chlorpyrifos i.e. 10 ppm in loamy sand soil as reported by Satpathy., et al (1993). The effect of chlorpyrifos was evaluated on cellulase activity in cultivated soil of Rajkot Gujarat. Chlorpyrifos application lead to significant increase in cellulase activity till initial incubation period. In comparison to control, cellulase activity increased 36\% in presence of 10 ppm chlorpyrifos. After 14 days the chlorpyrifos showed inhibitory effect at higher concentration similarly in Kumar Sumit [28] who found the maximum inhibition up to $28 \%$ in presence of 100 ppm after 7 days of incubation period.

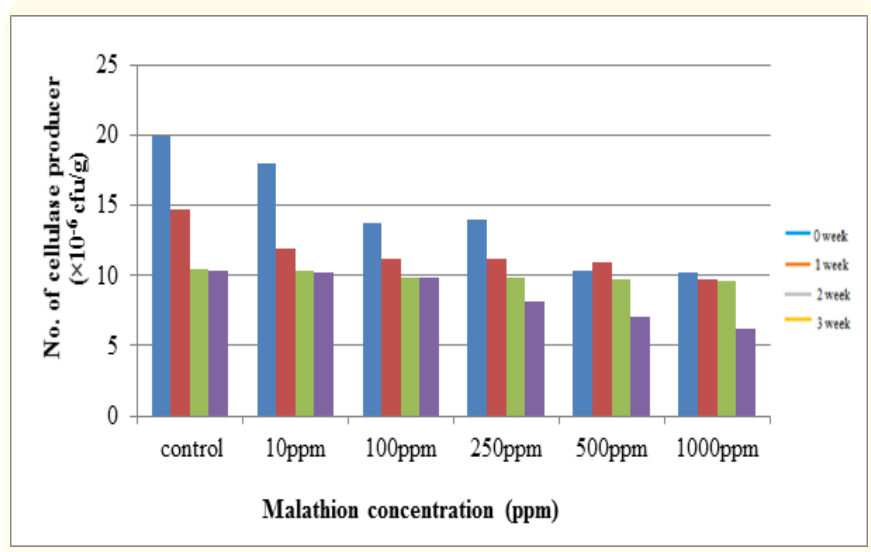

Figure 17: Effect of different concentration of malathion on cellulase activity.

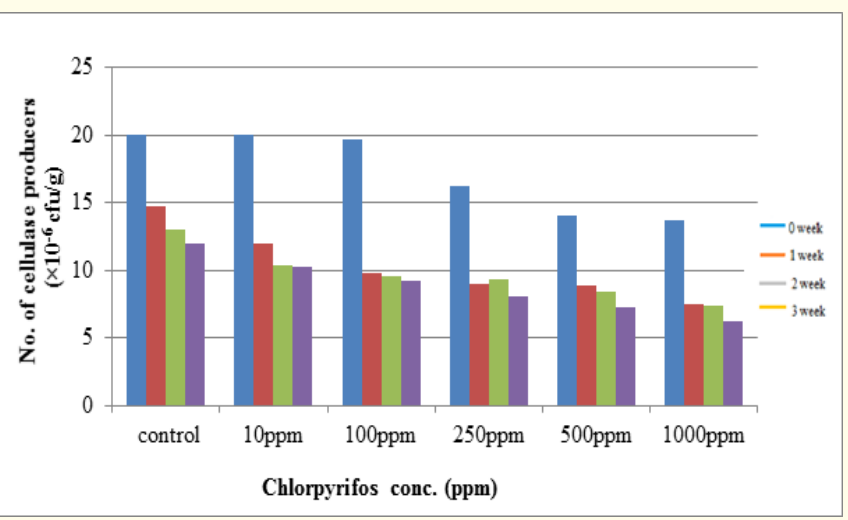

Figure 18: Effect of different concentration of chlorpyrifos on cellulase producers.

\section{Conclusion}

Our present study interpreted that the use of Malathion $(50 \% \mathrm{EC})$ and chlorpyrifos (20\%) at lower concentration (10 ppm to $250 \mathrm{ppm}$ ) was beneficial and enough effective to fight against pests but higher concentration ( $\geq 500 \mathrm{ppm}$ ) leads to reduction in microbial and enzyme activity in soil. It was also concluded that persistence of both pesticides for 21 days was tolerable as there was no deleterious effect of this pesticide was found. Our research examined that Malathion was more empathetic than chlorpyrifos in toxicity. Variation in result was observed it may be due to various environmental factors, soil properties and texture. For better understanding, this research area merits enhanced future research based on molecular techniques, contrary to traditional approaches, which are used for quantification of net impact of malathion and chlorpyrifos on soil biology and biochemistry.

\section{Bibliography}

1. Laabs V., et al. "Pesticide fate in tropical wetlands of Brazil: An aquatic microcosm study under semi-field conditions". Che mosphere 67.5 (2007): 975-989.

2. Weber JB., et al. "Calculating pesticide sorption coefficients (K sub (d)) using selected soil properties". Chemosphere 55 (2004): 157-166.

3. Walia A., et al. "Impact of fungicide mancozeb at different application rates on soil microbial populations, soil biological processes and enzyme activities in soil". The Scientific World Journal (2014): 1-9.

4. Haleem AM., et al. "Effect of some organophosphorus insecticides on soil microorganisms populations under lab condition". World Environment 3.5 (2013): 170-173.

5. Araujo AS., et al. "Effect of glyphosphate on the microbial activity of two Brazilian soils". Chemosphere 52.5 (2003): 799804.

6. Hindumathy CK and Gayathri V. "Effects of chlorpyrifos on soil microbial flora and pesticide, Degradation by strains isolated from contaminated soils". Bioremediation and Biodegradation 4 (2013): 178.

7. Kay Lynn Newhart. "Environmental Fate of Malathion". California Environmental Protection Agency Department of Pes ticide Regulation Environmental Monitoring Branch (2006).

8. Sarnaik SS., et al. "Effect of application of different pesticides to soyabean on the soil micro-flora". Journal of Environmental Biology 27.2 (2006): 423-426.

9. Pandey S and Singh DK. "Total bacterial and fungal population after chlorpyrifos and quinalphos treatments in groundnut (Arachis hypogeal L.) soil". Chemosphere 55.2 (2004): 197205.

10. Rani MS., et al. "Isolation and characterization of chlorpyrifos degrading bacteria from agricultural soil and growth response". African Journal of Microbiology Research 2 (2008) 
026-031.

11. Smith MD., et al. "Effect of long term application on microbial properties in tallgrass practice soil". Soil Biology and Biochemistry 32 (2000): 935-946.

12. Tarek M., et al. "Pesticide fungi interaction and their impact on fungal population in agricultural soil". International Journal of Microbiology and Allied Sciences 1.4 (2015): 18-22.

13. Ramadevi C., et al. "Mycodegradation of malathion by a soil fungal isolate Aspergillus niger". International Journal of Basic and Applied Chemical Sciences 2.1 (2012): 108-155.

14. Bisht J., et al. "Effect of repeated application of chlorpyrifos on fungal population of pine forest soil". Journal of Forestry Research and Education 142.3 (2016).

15. Ahmed S and Ahmad MS. "Effect of insecticide on the total number of soil bacteria under laboratory and field conditions". Emtomology 28 (2006): 2.

16. Phillip C., et al. "Effect of organochlorine pesticides on growth of actinomycetes". Indian Journal of Scientific Research 4.1 (2014):191-195.

17. Supreeth M., et al. "Effect of chlorpyrifos on soil microbial diversity and its biotransformation by Streptomyces sp. HP-11". Biotech 6 (2016): 147.

18. Shan M., et al. "Effect of chlorpyrifos on soil microbial populations and enzyme activities". Journal of Environmental Science 18.1 (2006): 4-5.

19. Mahanta B. "Effect of Malathion on Microbial Population, Acid and Alkaline Phosphatase Activity of Soil". International Journal of Science and Research 5.3 (2014): 2319-7064.

20. Dehingia B and Dutta BK. "A case study on the effect of pesticides on soil microbial enzymes: alkaline phosphatase and nitrate reductase". Journal of Frontline Research in Arts and Science 2 (2012): 128-133.

21. Menon B., et al. "Matrix metalloproteinases mediate beta-adrenergic receptor stimulated apoptosis in adult rat ventricular myocyte". Physiology of Cell Physiology 289.1 (2005): C168C176.

22. Jastrzebska E and Kucharski J. "Dehyrogenase, ureases and phosphatase activities of soil contaminated with fungicide". Soil Ecology Environment and Conservation 53 (2007): 51-57.

23. Juan CSH., et al. "Short term response of soil enzyme activity in a chlorpyrifos-treated mescasm: use of emzyme based indexes". Ecological Indicators 73 (2017): 525-535.

24. Vijay AKB., et al. "Activities of cellulase and amylase in soils as influenced by insecticide interactions". Ecotoxicology and Environmental Safety 68.2 (2007): 278-285.

25. Wu J., et al. "Effect of micro-remediation on enzyme activity and available nutrients in chlorpyrifos polluted soil". Agriculture, Forestry and Fisheries 6.5 (2017): 166-172.

26. Madella NR and Venkateswarlu K. "Impact of acephate and buprofezin on soil enzymes". Insecticides-Soil Microbiota Interactions (2018): 57-64.

27. Omar SA and Abdel SMA. "Microbial populations and enzyme activities in soil treated with pesticides". Water Air Soil Pollution 127.1-4 (2001): 49-63.

28. Kumar S. "Soil cellulase activity in response to application of endosulfan and chlorpyrifos". Electronic Journal of Environmental Science 4 (2011): 61-65.

\section{Volume 1 Issue 4 April 2018 \\ (C) All rights are reserved by Abhishek Walia., et al.}

